\title{
APLIKASI PRESENSI PERKULIAHAN DENGAN FINGERPRINT BERBASIS WEB DAN SMS GATEWAY (Studi Kasus Universitas Kuningan)
}

\author{
Rio Andriyat Kris diawan, M.Kom ${ }^{1}$, Dede Irawan, M.Kom ${ }^{2}$ \\ Fakultas Ilmu Komputer Universitas Kuningan \\ Jalan Tjut Nyak Dhien No. 36 A Cijoho Kuningan Jawa Barat 45513 Telepon (0232) 2875097 \\ rioandriyat@uniku.com ${ }^{1}$, dedeirawan@uniku.ac.id ${ }^{2}$
}

Kegiatan perkuliahan di perguruan tinggi Universitas Kuningan (UNIKU) tidak lepas dari proses presensi. Baik itu proses presensi dosen dan juga mahasiswa. Proses presensi dilingkungan universitas kuningan sangat berpengaruh terhadap proses perkuliahan bagi mahasiswa, penggajian terhadap dosen, dan proses pelayanan kualiatas perkuliahan universitas kuningan.

Proses presensi di lingkungan universitas kuningan masih dilakukan secara manual, yaitu dengan menulis dan mengabsen di Daftar Hadir Mahasiswa dan Dosen (DHMD). Proses tersebut masih memiliki banyak kekurangan, seperti masih adanya mahasiswa yang menitipkan absensi berupa tanda tangan di DHMD, masih perlunya melakukan rekap presensi pada saat akan melakukan pelaporan data, dan mudah rusak/hilangnya DHMD ketika akan melakukan pengelolaan data. Selain itu, mahasiswa terkadang tidak dapat mengetahui secara langsung informasi perhitungan presensi perkuliahan yang sudah dilakukan.

Berdasarkan uraian diatas, peneliti akan membangun sebuah aplikasi presensi perkuliahan dengan menggunakan fingerprint sebagai alat yang digunakan dalam proses input presensi, serta membuat sebuah aplikasi pengelolaan presensi yang efektif dan efisien dalam membantu pengelolaan presensi, serta service sms gateway sebagai notifikasi informasi perhitungan presensi kepada mahasiswa dan dosen yang akan dibangun dengan Bahasa pemrograman PHP dengan database MySQL.Serta konsep jaringan client server yang mana semua pusat data presensi akan disimpan di computer server yang akan memberikan service sms gateway.

Implementasi akan dilakukan sesuai dengan matakuliah, dosen, kelas, ruangan, dan watu perkuliahan yang ada di Universitas Kuningan, dikhususkan di Fakultas Ilmu Komputer Universitas Kuningan. Dan pengujian dilakukan terhadap data presensi yang diinput dengan scanner fingerprint melalui aplikasi dan database yang sudah dibangun.

Kata Kunci : SMS Gateway, Fingerprint, Presensi, Perkuliahan, PHP dan MySQL

The process of attendance at the Kuningan university environment greatly influences the lecture process for students, payroll for lecturers, and the process of quality services for the brass university lectures. The process of presence in the Kuningan university is still done manually, namely by writing and attending the Student and Lecturer Attendance List (DHMD). The process still has many shortcomings, such as there are still students who leave attendance in the form of signatures on DHMD, there is still a need to do a prescription when reporting data, and easily damage / lose DHMD when managing data. In addition, students sometimes cannot know directly the information on the attendance calculation of lectures that have been conducted. Based on the description above, the researcher will build a lecture presence application using fingerprint as a tool used in the presence input process, and create an effective and efficient presence management application to assist attendance management, as well as service sms gateway as notification of attendance calculation information to students and lecturers will be built with the PHP programming language with MySQL databases. As well as the concept of client server networks where all attendance data centers will be stored on the computer server that will provide the service sms gateway. The implementation will be carried out in accordance with the courses, lecturers, classes, rooms, and lectures at the University of Kuningan, specifically at the Faculty of Computer Science, Kuningan University. And testing is carried out 
on presence data inputted with a fingerprint scanner through applications and databases that have been built.

Keywords: SMS Gateway, Fingerprint, Presence, Lecture, PHP and MySQL

\section{PENDAHULUAN}

Kegiatan perkuliahan di perguruan tinggi Universitas Kuningan (UNIKU) tidak lepas dari proses presensi. Baik itu proses presensi dosen dan juga mahasiswa. Presensi adalah kegiatan dalam pengambilan data guna mengetahui jumlah kehadiran dari suatu acara (Perkuliahan). Proses presensi dilingkungan universitas kuningan sangat berpengaruh terhadap proses perkuliahan bagi mahasiswa, penggajian terhadap dosen, dan proses pelayanan kualiatas perkuliahan universitas kuningan.

Salah satu kegunaan proses presensi untuk mahasiswa yaitu untuk mengetahui perhitungan kehadiran mahasiswa sebagai syarat mengikuti ujian akhir semester. Dan untuk institusi UNIKU sebagai perhitungan penggajian dosen selama melakukan perkuliahan dan juga sebagai tolak ukur untuk mengetahui kualitas dosen dalam melakukan kegiatan perkuliahan sesuai dengan aturan minimal kehadiran yang sudah ditetapkan oleh institusi.

Proses presensi di lingkungan universitas kuningan masih dilakukan secara manual, yaitu dengan menulis dan presensi di Daftar Hadir Mahasiswa dan Dosen (DHMD). Proses tersebut masih memiliki banyak kekurangan, seperti masih adanya mahasiswa yang menitipkan presensi berupa tanda tangan di DHMD, masih perlunya melakukan rekap presensi pada saat akan melakukan pelaporan data, dan mudah rusak/hilangnya DHMD ketika akan melakukan pengelolaan data. Selain itu, mahasiswa terkadang tidak dapat mengetahui secara langsung informasi presensi perkuliahan yang sudah dilakukan.

Perkembangan teknologi di dunia semakin pesat baik itu hardware maupun software, khususnya kemajuan di bidang teknologi informasi terutama pada teknologi mobile dan internet. Penggunaan aplikasi mobile dan web dikatakan lebih efektif dan efisien karena adanya kemudahan dalam pengaksesan dan pengambilan informasi.

Perkembangan media informasi salah satunya tentang SMS Gateway, yaitu sebuah gerbang yang menghubungkan antara komputer dengan client melalui SMS. Client secara tidak langsung berinteraksi dengan aplikasi / sistem melalui SMS Gateway. Saat melakukan SMS, maka informasi terpenting yang diperlukan adalah nomor tujuan dan pesan, maka itulah yang sebenarnya diolah oleh SMS Gateway. Contoh aplikasi SMS Gateway dalam penerapannya di dunia akademik saat ini adalah pengumuman beasiswa, pengumuman ruang tes, dan lain sebagainya. Pengumuman-pengumuman tersebut dilakukan secara otomatis satu arah oleh sistem sebagai notifikasi dan sms autoreply.

Perkembangan teknologi hardware juga sangat berpengaruh terhadap input, proses, dan output yang dilakukan terhadap suatu sistem. Seperti teknologi hardware berupa piranti input seperti fingerprint yang memberikan kemudahan input bahkan validai input yang sangat akurat yang bisa digunakan dalam proses presensi. Dengan teknologi input fingerprint, dapat meminimalisir kesalahan input bahkan kecurangan input ke sistem.

Berdasarkan latar belakang diatas, dibutuhkan suatu aplikasi yang dapat mengelola presensi perkuliahan yang dapat membantu proses presensi dimulai dari proses presensi yang mudah dan akurat, pengelolaan presensi yang lebih efektif dan efisien serta pelaporan presensi yang praktis dan tersistematis. Selain itu harus adanya service tentang informasi presensi perkuliahan yang berlangsung kepada mahasiswa dan dosen sebagai notifikasi.

Dari latarbelakang diatas, maka dapat diketahui rumusan masalah sebagai berikut :

1. Belum adanya aplikasi presensi perkuliahan yang memiliki keakuratan dalam proses input presensi yang dilakukan oleh mahasiswa dan dosen.

2. Belum adanya aplikasi yang dapat mengelola presensi perkuliahan sebagai pelaporan dan notifikasi perhitungan kehadiran bagi mahasiswa dan dosen.

3. Belum adanya aplikasi presensi yang terintegrasi dengan aplikasi akademik lain yang mudah diakses oleh civitas akademik Universitas Kuningan.

4. Bagaimana membangun aplikasi presensi dengan menggunakan fingerprint dan 
bahasa pemrograman berbasis web, serta notifikasi dengan SMS Gateway.

5. Bagaimana mengintegrasikan input presensi fingerprint dengan skema jadwal yang akan dikelola di aplikasi berbasis web.

Batasan masalah dalam penelitian ini adalah:

1. Implementasi aplikasi presensi perkuliahan dengan fingerprint berbasis web dan sms gateway akan diimplementasikan di Fakultas Ilmu Komputer Universitas Kuningan.

2. Input presensi dan validasi akan menggunakan alat fingerprint reader U4500.

3. Fingerprint reader akan ditempatkan disemua ruangan perkuliahan Fakultas Ilmu Komputer (FKOM) UNIKU, dengan station PC/Laptop yang terkoneksi jaringan ke server.

4. Service notifikasi dan sms autoreply informasi presensi akan dibangun dengan menggunakan service Gammu SMS Gateway.

5. Aplikasi persensi akan dibangun dengan menggunakan bahasa pemrograman PHP dan database MySQL yang terdiri dari :

a. Aplikasi dapat menerima input dari fingerprint reader.

b. Aplikasi dapat mengelola jadwal perkuliahan berdasarkan matakuliah, dosen, kelas, ruangan, dan watu perkuliahan.

c. Entitas/aktor yang dapat berinteraksi dengan aplikasi yaitu : Admin, Staf TU, Dosen, Mahasiswa, dan Kepala Program Studi.

d. Pelaporan dapat di buat secara persession, per-hari, per-minggu dan rekap keseluruhan dengan output format excel dan PDF.

e. Notifikasi dan sms autoreply informasi presensi didimpan di database MySQL dengan service Gammu SMS Gateway.

Tujuan dari penelitian adalah Untuk membangun aplikasi presensi perkuliahan dengan finger print berbasis web dan sms gateway sebagai media pemantau, perekam dan pelaporan informasi presensi perkuliahan. Manfaat dari penelitian ini adalah Memanfaatkan Fingerprint Scanner sebagai media perekam absensi mahasiswa dan dosen dalam melaksanakan perkuliahan dan aplikasi presensi berbasis web dan sms gateway dengan tujuan mempermudah mendapatkan informasi presensi dan pelaporan presensi perkuliahan di FKOM Universitas Kuningan. Dan Dari sisi akademis, hasil penelitian ini semoga dapat menambah kepustakaan keilmuan dalam tahapan dan pengembangan proses absensi di fakultas ilmu komputer. Dari hasil penelitian in, selanjutnya akan dipublikasikan pada jurnal sebagai sharing knowledge

\section{METODELOGI PENELITIAN}

\subsection{Metode Pengembangan Sistem}

Metodologi yang digunakan oleh penulis dalam melakukan penelitian ini adalah RUP (Rational Unified Process). Rational Unified Process merupakan suatu metode rekayasa perangkat lunak yang dikembangkan dengan mengumpulkan berbagai best practises yang terdapat dalam industri pengembangan perangkat lunak. Ciri utama metode ini adalah menggunakan use-case driven dan pendekatan iteratif untuk siklus pengembangan perankat lunak.

Model RUP sangat bagus digunakan untuk proses pengembangan perangkat lunak berbasis Unified Modeling Language (UML). Hal ini dikarenakan metode RUP memakai cara-cara Object Oriented Programming (OOP) dalam membagi tahapan demi tahapan dan iterasi antar komponen yang terlibat.

RUP menggunakan konsep object oriented, dengan aktifitas yang berfokus pada pengembangan model dengan menggunakan Unified Model Language (UML). RUP memiliki 2 dimensi pengembangan, yaitu:

1. Dimensi pertama digambarkan secara horizontal. Dimensi ini mewakili aspekaspek dinamis dari pengembangan perangkat lunak. Aspek ini dijabarkan dalam tahapan pengembangan atau fase. Setiap fase akan memiliki suatu major milestone yang menandakan akhir dari awal dari phase selanjutnya. Setiap phase dapat berdiri dari satu beberapa iterasi. Dimensi ini terdiri atas Inception, Elaboration, Construction, dan Transition.

2. Dimensi kedua digambarkan secara vertikal. Dimensi ini mewakili aspek-aspek statis dari proses pengembangan perangkat 
lunak yang dikelompokkan ke dalam beberapa disiplin. Proses pengembangan perangkat lunak yang dijelaskan kedalam beberapa disiplin terdiri dari empat elemen penting, yakni who is doing, what, how dan when. Dimensi ini terdiri atas; Business Modeling, Requirement, Analysis and Design, Implementation, Test, Deployment, Configuration dan Change Manegement, Project Management, Environtment.

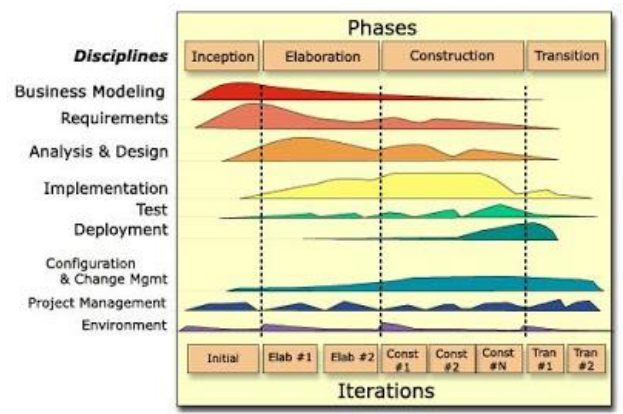

Gambar 1. Gambar Fase RUP

Gambar 1 menjelaskan 4 tahapan yang ada dalam metode RUP. Tahap- tahap dari metode RUP tersebut dapat diuraikan sebagai berikut:

1. Tahap Inception

Tahap inception adalah tahapan yang fokus pada penentuan manfaat aplikasi perangkat lunak yang harus dihasilkan.

2. Tahap Elaboration

Tahap elaboration adalah tahapan yang digunakan untuk menentukan use case(set of activities) dari perangkat lunak berikut rancangan arsitekturnya.

3. Tahap Construction

Tahap construction berisi tahapan pengimplementasian rancangan aplikasi perangkat lunak yang telah dibuat lengkap dan siap diserahkan kepada pemakai.

4. Tahap Transition

Tahap transition adalah tahapan untuk menyediakan sistem untuk digunakan oleh pemakai.

\subsection{Teknik Pengumpulan Data}

1. Metode Wawancara

Metode wawancara adalah suatu metode pengumpulan data dengan cara melakukan tanya jawab secara langsung terhadap pihak-pihak yang terkait sesuai dengan bidang dan ilmunya masingmasing, khusunya dalam presensi di FKOM UNIKU.
Metode wawancara digunakan ketika mencari data tentang proses presensi perkuliahan dari dosen sampai tahap pelaporan presensi.

2. Metode Observasi

Metode observasi adalah suatu metode pengumpulan data dengan cara melakukan pengamatan langsung terhadap obyek yang akan diteliti serta pencatatan secara cermat dan sistematis. Obyek yang diamati disini adalah Fakultas Ilmu Komputer Universitas Kuningan.

3. Metode Studi Literatur/pustaka

Metode studi literatur adalah suatu metode pengumpulan data dengan menggunakan literatur yang bisa dipakai seperti dengan memanfaatkan fasilitas Internet, yaitu dengan mengunjungi situssitus web yang berhubungan dengan perancangan sistem, fingerprint, juga dengan menggunakan buku-buku sebagai bahan referensi dalam mencari dan mendapatkan informasi-informasi yang dibutuhkan.

\section{HASIL DAN PEMB AHASAN}

3.1 Analisis Sistem yang Diusulkan

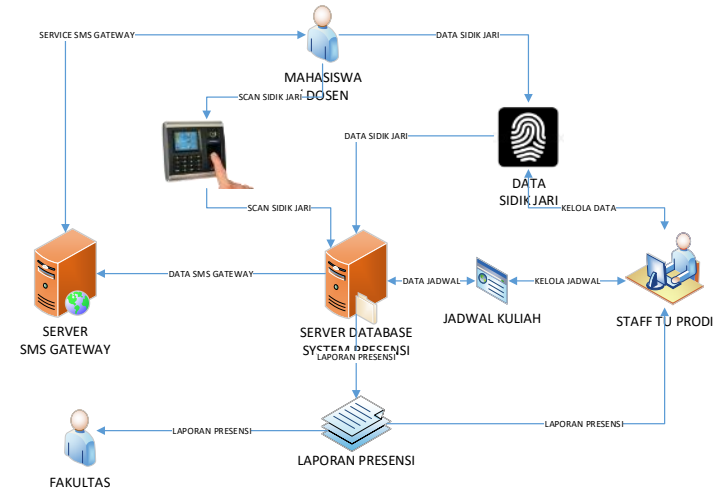

Gambar 2. Rich Picture Sistem yang diusulkan

\subsection{Perancangan Use Case Diagram}




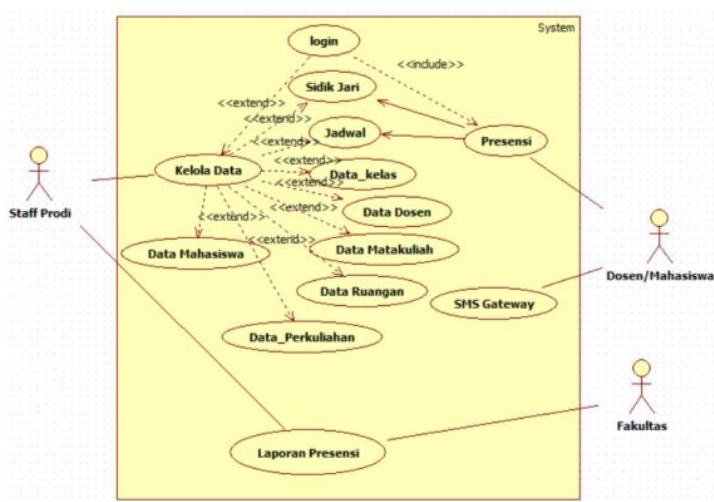

Gambar 3. Use case diagram sistem

Pada gambar 3 use case diagram akan di deskripsikan sebagai berikut :

\section{a. Skenario Use Case Login}

Tabel 1. Skenario UseCase Login

\begin{tabular}{|c|c|c|}
\hline $\begin{array}{l}\text { Nama Use } \\
\text { Case }\end{array}$ & \multicolumn{2}{|l|}{ Login } \\
\hline Aktor & \multicolumn{2}{|l|}{ Staff Prodi } \\
\hline Deskripsi & \multicolumn{2}{|c|}{$\begin{array}{l}\text { Proses Ini adalah sebuah } \\
\text { untuk masuk ke dalam } \\
\text { Presensi Aplikasi } \\
\text { Fingerprint Berkuliahan } \\
\text { Gateway (Studi Kasus Universitas } \\
\text { Kuningan). }\end{array}$} \\
\hline \multirow[t]{2}{*}{$\begin{array}{l}\text { Kondisi } \\
\text { Normal }\end{array}$} & Staff Prodi & Reaksi Sistem \\
\hline & $\begin{array}{l}\text { 1.Mengisi } \\
\text { username } \\
\text { dan } \\
\text { password. }\end{array}$ & 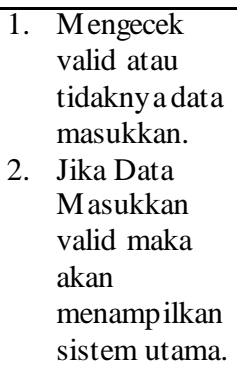 \\
\hline \multirow{2}{*}{$\begin{array}{l}\text { Kondisi } \\
\text { Alternatif }\end{array}$} & Staff Prodi & Reaksi Sistem \\
\hline & $\begin{array}{l}\text { 1. Mengisi } \\
\text { username dan } \\
\text { password. }\end{array}$ & $\begin{array}{ll}\text { 1. } & \text { Mengecek } \\
\text { valid atau } \\
\text { tidaknya data } \\
\text { masukkan. } \\
\text { 2. Jika data } \\
\text { masukkan } \\
\text { salah, maka } \\
\text { akan } \\
\text { memberitahu } \\
\text { pesan } \\
\text { peringatan. }\end{array}$ \\
\hline $\begin{array}{l}\text { Pre- } \\
\text { Condition }\end{array}$ & \multicolumn{2}{|c|}{ Staff Prodi akan melakukan Login } \\
\hline $\begin{array}{l}\text { Post- } \\
\text { Condition }\end{array}$ & \multicolumn{2}{|c|}{$\begin{array}{l}\text { Mengisi username dan password } \\
\text { untuk masuk ke sistem. }\end{array}$} \\
\hline
\end{tabular}

\section{b. Skenario Use Case Kelola Data} Tabel 2. Skenario UseCase Kelola Data

\begin{tabular}{|l|l|}
\hline Nama & Kelola Data \\
Use Case & \\
\hline
\end{tabular}

p-ISSN : 2527-4856, e-ISSN : 2614-5413

https ://journal.uniku.ac.id/index.php/buffer

\begin{tabular}{|c|c|c|}
\hline Aktor & \multicolumn{2}{|l|}{ Staff Prodi } \\
\hline Deskripsi & \multicolumn{2}{|c|}{$\begin{array}{l}\text { Proses Ini adalah sebuah kegiatan untuk } \\
\text { mengelola data sidik jari, dan jadwal } \\
\text { perkuliahan. }\end{array}$} \\
\hline \multirow{2}{*}{$\begin{array}{l}\text { Kondisi } \\
\text { Normal }\end{array}$} & Staff Prodi & Reaksi Sistem \\
\hline & $\begin{array}{l}\text { 1. Kelola data (input, } \\
\text { Edit, Delete) sidik } \\
\text { jari dan jadwal } \\
\text { perkuliahan, } \\
\text { mahasiswa, dosen, } \\
\text { kelas, ruangan, } \\
\text { matakuliah }\end{array}$ & $\begin{array}{ll}\text { 3. } & \text { Mengecek } \\
\text { valid atau } \\
\text { tidaknya } \\
\text { data } \\
\text { masukkan. } \\
\text { 4. Jika Data } \\
\text { Masukkan } \\
\text { valid } \\
\text { maka akan } \\
\text { memberik } \\
\text { an pesan } \\
\text { sukses. }\end{array}$ \\
\hline \multirow[t]{2}{*}{$\begin{array}{l}\text { Kondisi } \\
\text { Alternatif }\end{array}$} & Staff Prodi & Reaksi Sistem \\
\hline & $\begin{array}{l}\text { 2. Kelola data (input, } \\
\text { Edit, Delete) sidik } \\
\text { jari dan jadwal } \\
\text { perkuliahan, } \\
\text { mahasiswa, dosen, } \\
\text { kelas, ruangan, } \\
\text { matakuliah }\end{array}$ & 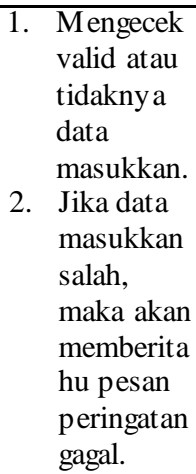 \\
\hline $\begin{array}{l}\text { Pre- } \\
\text { Condition }\end{array}$ & \multicolumn{2}{|c|}{$\begin{array}{l}\text { Staff Prodi berhasil melakukan kelola } \\
\text { data sidik jari dan jadwal. }\end{array}$} \\
\hline $\begin{array}{l}\text { Post- } \\
\text { Condition }\end{array}$ & \multicolumn{2}{|c|}{$\begin{array}{l}\text { Mengisi dapat melihat, menambahkan, } \\
\text { mengedit, data master yang disimpan di } \\
\text { database. }\end{array}$} \\
\hline
\end{tabular}

\section{c. Skenario Use Case Presensi}

Tabel 3. Skenario UseCase Presensi

\begin{tabular}{|c|c|c|}
\hline $\begin{array}{l}\text { Nama } \\
\text { Use Case }\end{array}$ & \multicolumn{2}{|l|}{ Presensi } \\
\hline Aktor & \multicolumn{2}{|l|}{ Dosen dan Mahasiswa } \\
\hline Deskripsi & \multicolumn{2}{|c|}{$\begin{array}{l}\text { Proses Ini adalah sebuah kegiatan untuk } \\
\text { melakukan presensi perkuliahan sesuai } \\
\text { dengan jadwal }\end{array}$} \\
\hline \multirow{2}{*}{$\begin{array}{l}\text { Kondisi } \\
\text { Normal }\end{array}$} & Dosen dan Mahasiswa & Reaksi Sistem \\
\hline & $\begin{array}{l}\text { 1. Dosen melakukan } \\
\text { scan sidik jari, dan } \\
\text { diikuti oleh } \\
\text { mahasiswa untuk } \\
\text { melakukan } \\
\text { presensi sesuai } \\
\text { jadwal. }\end{array}$ & $\begin{array}{ll}\text { 1. } & \text { Mengecek } \\
\text { valid atau } \\
\text { tidaknya } \\
\text { data scan } \\
\text { sidik jari. } \\
\text { 2. Jika Data } \\
\text { Masukkan } \\
\text { valid } \\
\text { maka akan } \\
\text { memberik } \\
\text { an pesan } \\
\text { sukses. }\end{array}$ \\
\hline $\begin{array}{l}\text { Kondisi } \\
\text { Alternatif }\end{array}$ & Dosen dan Mahasiswa & Reaksi Sistem \\
\hline
\end{tabular}


JURNAL BUFFER INFORMATIKA

Volume 4 Nomor 2, Oktober 2018

\begin{tabular}{|c|c|c|}
\hline & $\begin{array}{l}\text { 1. Dosen melakukan } \\
\text { scan sidik jari, dan } \\
\text { diikuti oleh } \\
\text { mahasiswa untuk } \\
\text { melakukan } \\
\text { presensi sesuai } \\
\text { jadwal. }\end{array}$ & 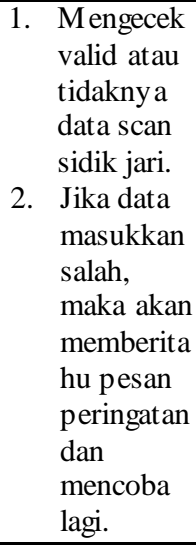 \\
\hline $\begin{array}{l}\text { Pre- } \\
\text { Condition }\end{array}$ & \multicolumn{2}{|c|}{$\begin{array}{l}\text { Dosen melakukan scan sidik jari, dan } \\
\text { diikuti oleh mahasiswa untuk melakukan } \\
\text { presensi sesuai jadwal. }\end{array}$} \\
\hline $\begin{array}{l}\text { Post- } \\
\text { Condition }\end{array}$ & \multicolumn{2}{|c|}{$\begin{array}{l}\text { Data scan sidik jari untuk presensi } \\
\text { berhasil dimasukan ke sistem. }\end{array}$} \\
\hline
\end{tabular}

d. Skenario Use Case Sms Gate way

Tabel 4. Skenario UseCase Sms Gateway

\begin{tabular}{|c|c|c|}
\hline $\begin{array}{l}\text { Nama } \\
\text { Use Case }\end{array}$ & \multicolumn{2}{|l|}{ SMS Gateway } \\
\hline Aktor & \multicolumn{2}{|c|}{ Dosen dan Mahasiswa } \\
\hline Deskripsi & \multicolumn{2}{|c|}{$\begin{array}{l}\text { Proses Ini adalah service informasi } \\
\text { presensi dan jadwal untuk dosen dan } \\
\text { mahasiswa melalui SMS Gateway. }\end{array}$} \\
\hline $\begin{array}{l}\text { Kondisi } \\
\text { Normal }\end{array}$ & $\begin{array}{l}\text { Dosen dan } \\
\text { Mahasiswa }\end{array}$ & Reaksi Sistem \\
\hline & $\begin{array}{l}\text { 1. Dosen dan } \\
\text { mahasiswa } \\
\text { mengirimkan } \\
\text { sms ke } \\
\text { system sesuai } \\
\text { format untuk } \\
\text { mengetahui } \\
\text { informasi } \\
\text { presesnsi dan } \\
\text { jadwal. }\end{array}$ & $\begin{array}{ll}\text { 1. } & \text { Mengecek valid } \\
\text { atau tidaknya } \\
\text { format SMS. } \\
\text { 2. Jika Format } \\
\text { SMS valid } \\
\text { maka system } \\
\text { Mengirim SMS } \\
\text { ke Tujuan }\end{array}$ \\
\hline $\begin{array}{l}\text { Kondisi } \\
\text { Alternatif }\end{array}$ & $\begin{array}{l}\text { Dosen dan } \\
\text { Mahasiswa }\end{array}$ & Reaksi Sistem \\
\hline & $\begin{array}{l}\text { 2. Dosen dan } \\
\text { mahasiswa } \\
\text { mengirimkan } \\
\text { sms ke } \\
\text { system sesuai } \\
\text { format untuk } \\
\text { mengetahui } \\
\text { informasi } \\
\text { presesnsi dan } \\
\text { jadwal. }\end{array}$ & $\begin{array}{ll}\text { 1. } & \text { Mengecek valid } \\
\text { atau tidaknya } \\
\text { format SMS. } \\
\text { 2. Jika Format } \\
\text { SMS tidak } \\
\text { valid maka } \\
\text { system } \\
\text { Mengirim SMS } \\
\text { peringatan } \\
\text { Format SMS } \\
\text { tidak sesuai. }\end{array}$ \\
\hline $\begin{array}{l}\text { Pre- } \\
\text { Condition }\end{array}$ & \multicolumn{2}{|c|}{$\begin{array}{l}\text { Dosen dan Mahasiswa mengirimkan sms } \\
\text { sesuai format. }\end{array}$} \\
\hline $\begin{array}{l}\text { Post- } \\
\text { Condition }\end{array}$ & \multicolumn{2}{|c|}{$\begin{array}{l}\text { Dosen dan Mahasiswa mendapatkan } \\
\text { informasi presensi dan jadwal smelalui } \\
\text { service SMS Gateway. }\end{array}$} \\
\hline
\end{tabular}

\subsection{Activity Diagram}

p-ISSN : 2527-4856, e-ISSN : 2614-5413

https://journal.uniku.ac.id/index.php/buffer

Diagram activity akan menampilkan aliran kerja atau aktivitas dari sebuah sistem yang ada pada aplikasi. Di mana aktivitas ini akan menggambarkan aktivitas sistem dan bukan yang di lakukan oleh aktor terhadap aplikasi, jadi activity diagram ini akan menampilkan aktivitas-aktivitas yang dilakukan oleh system.

\section{a. Activity Diagram Login}

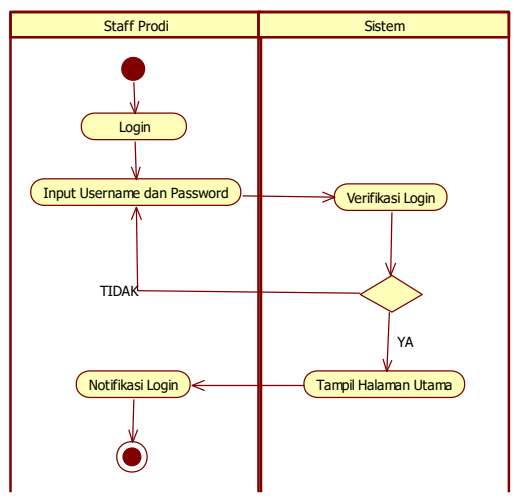

Gambar 4. Activity diagram Login

\section{b. Activity Diagram Kelola Data}

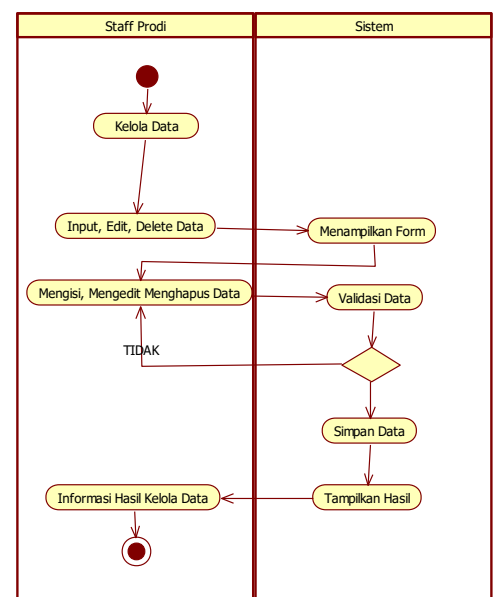

Gambar 5. Activity diagram Kelola Data c. Activity Diagram Presensi

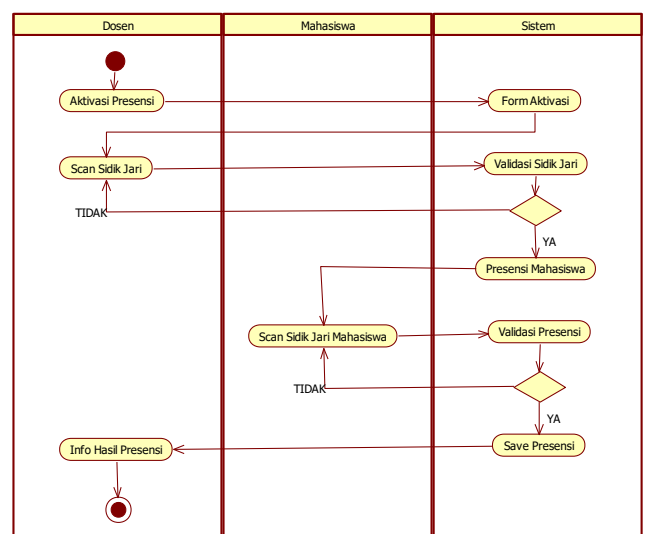

Gambar 6. Activity diagram presensi 


\section{d. Activity Diagram Sms Gateway}

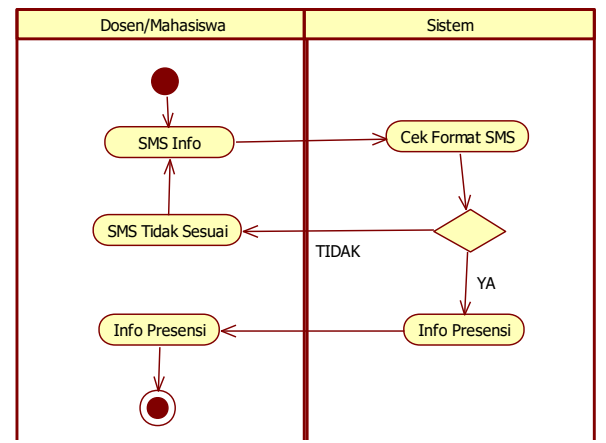

Gambar 7. Activity diagram Sms Gateway

\subsection{Class Diagram}

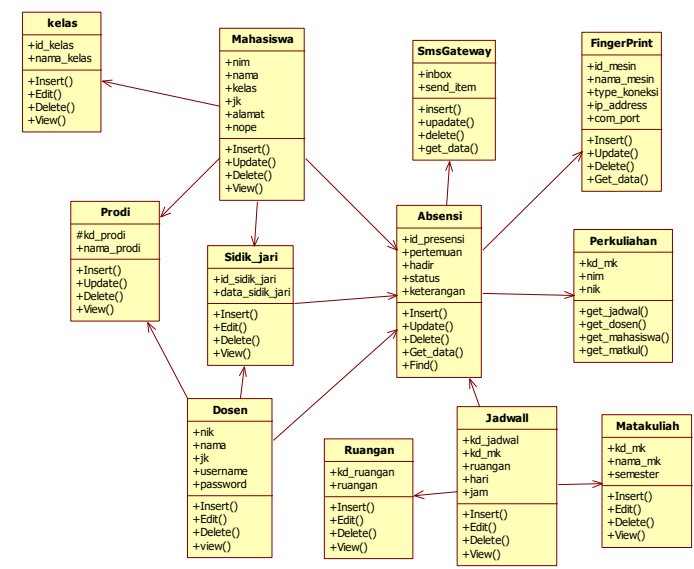

Gambar 8. Class Diagram

\subsection{Sequence Diagram}

\section{a. Sequence Diagram Login}

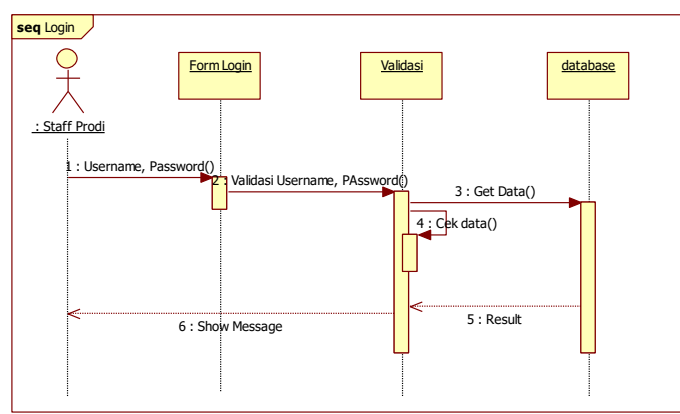

Gambar 9. sequence diagram Login

b. Sequence Diagram Kelola Data
p-ISSN : 2527-4856, e-ISSN : 2614-5413

https ://journal.uniku.ac.id/index.php/buffer

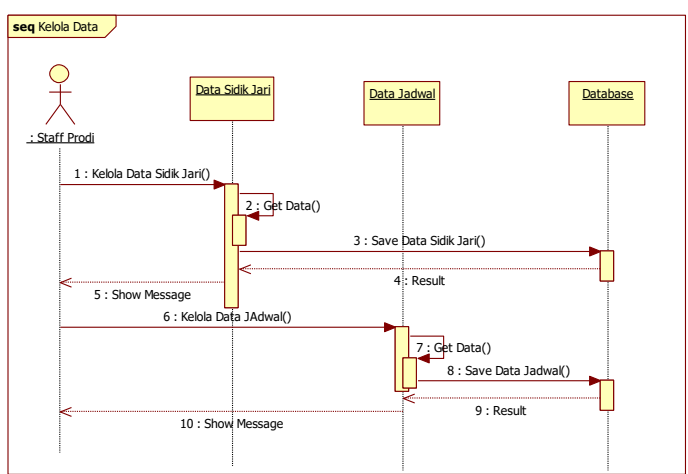

Gambar 10. Sequence diagram Kelola Data c. Sequence Diagram Presensi

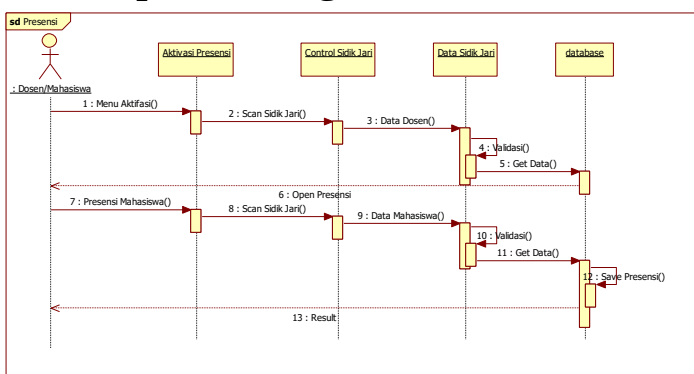

Gambar 11. Sequence diagram presensi d. Sequence Diagram Sms Gate way

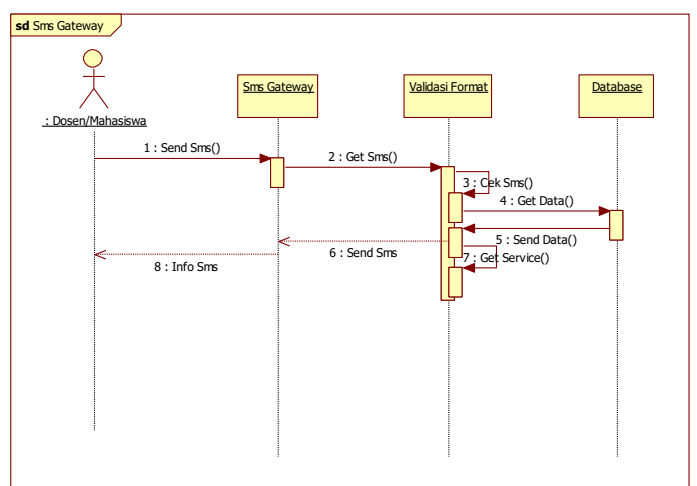

Gambar 12. Sequence diagram Sms Gateway Setelah tahapan Inception dan Elaboration dilakukan, maka selanjutnya akan dilakukan tahapan Construction dan Transition. Pada tahapan Construction akan lebih fokus pada hasil perancangan tampilan dan menu-menu yang diusulkan. Sementara itu, pada tahapan Transition lebih fokus pada proses pengujian dari aplikasi yang dirancang.

\subsection{Construction}

Setelah mengalami sederetan proses iterasi, pada tahapan Construction ini sudah dapat menghasilkan suatu aplikasi. Hasil dari aplikasi yang sudah dirancang dapat dilihat pada tampilan Gambar berikut :

1. Halaman Utama Aplikasi 


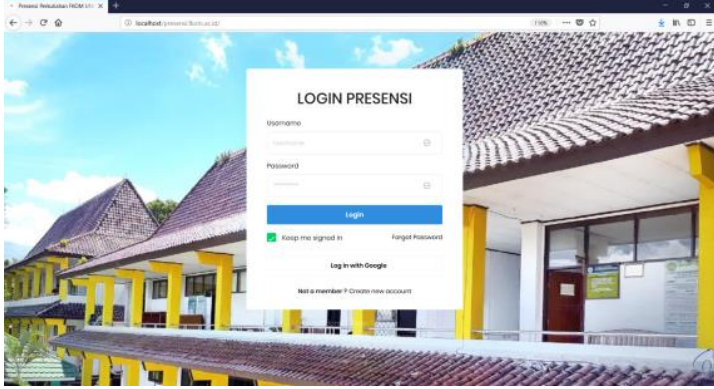

Gambar 13. Halaman Utama Aplikasi

2. Halaman Kelola Data Dosen

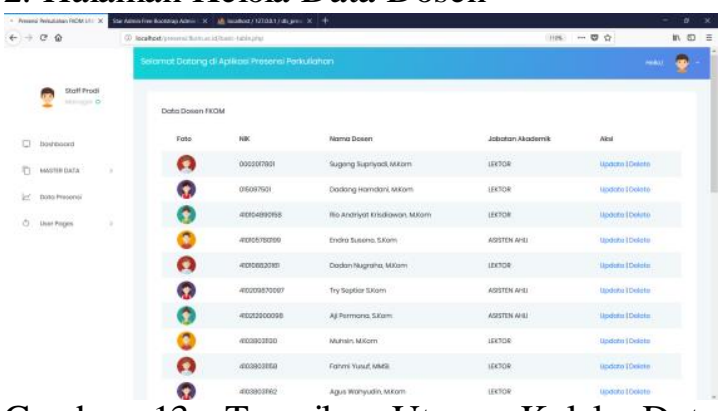

Gambar 13. Tampilan Utama Kelola Data Dosen.

\section{Halaman Menu Presensi}

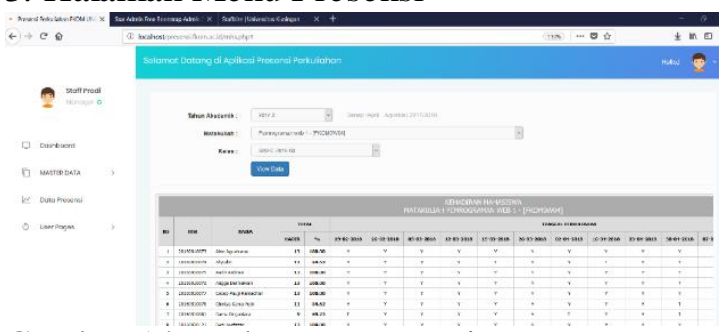

Gambar 14. Halaman Presensi

\subsection{Pengujian Perangkat Lunak}

Pengujian black box adalah proses pengujian aspek fundamental aplikasi tanpa memperhatikan struktur logika internal perangkat lunak. Proses pengujian ini dilakukan untuk mengetahui apakah aplikasi perangkat lunak dapat berjalan dan berfungsi dengan benar.

\section{Pengujian Black Box}

Pengujian black box merupakan suatu metode perancangan data uji yang didasarkan pada spesifikasi perangkat lunak. Hasil keluaran dari aplikasi perangkat lunak dicek apakah telah sesuai dengan yang diharapkan. Proses pengujian black box dilakukan pada Form Menu.

Tabel 5.Hasil Pengujian Black Box

\begin{tabular}{|l|l|l|l|l|}
\hline $\begin{array}{l}\mathbf{N} \\
\mathbf{0}\end{array}$ & $\begin{array}{l}\text { Fungsi } \\
\text { yang di } \\
\text { uji }\end{array}$ & $\begin{array}{l}\text { Cara } \\
\text { Menguji }\end{array}$ & $\begin{array}{l}\text { Hasil yang } \\
\text { diharapkan }\end{array}$ & $\begin{array}{l}\text { Hasil } \\
\text { yang } \\
\text { keluar }\end{array}$ \\
\hline 1 & $\begin{array}{l}\text { Cek } \\
\text { login }\end{array}$ & $\begin{array}{l}\text { Admin, TU } \\
\text { melakukan } \\
\text { login ke } \\
\text { system } \\
\text { dengan } \\
\text { memasukan } \\
\text { username } \\
\text { dan } \\
\text { password }\end{array}$ & $\begin{array}{l}\text { Tampil } \\
\text { Menu Utama } \\
\text { sesuai } \\
\text { dengan user }\end{array}$ & $\begin{array}{l}\text { Sesuai } \\
\text { dengan } \\
\text { harapan } \\
\text { Valid }\end{array}$ \\
& Menu & $\begin{array}{l}\text { User } \\
\text { melakukan } \\
\text { klik menu } \\
\text { pada } \\
\text { halaman } \\
\text { utama }\end{array}$ & $\begin{array}{l}\text { User dapat } \\
\text { berpindah } \\
\text { halaman }\end{array}$ & $\begin{array}{l}\text { Sesuai } \\
\text { dengan } \\
\text { harapan } \\
\text { Valid }\end{array}$ \\
\hline 3 & $\begin{array}{l}\text { Laporan } \\
\text { Presensi }\end{array}$ & $\begin{array}{l}\text { Dosen } \\
\text { melakukan } \\
\text { proses } \\
\text { laporan } \\
\text { presensi }\end{array}$ & $\begin{array}{l}\text { User dapat } \\
\text { mengakses } \\
\text { dan } \\
\text { mendapatkan } \\
\text { hasil laporan } \\
\text { presensi }\end{array}$ & $\begin{array}{l}\text { Sesuai } \\
\text { dengan } \\
\text { harapan } \\
\text { Valid }\end{array}$ \\
\hline
\end{tabular}

\section{Pengujian White Box}

Pengujian white box merupakan sebuah pengujian yang dilakukan dengan melihat kedalam modul dan kode-kode yang ada didalam aplikasi. Tujuannya adalah sebagai petunjuk untuk mendapatkan program yang benar secara menyeluruh sehingga sistem yang dirancang mampu menghasilkan interface dan output yang sesuai dengan kebutuhan. Secara sekilas dapat diambil kesimpulan white box testing merupakan petunjuk untuk mendapatkan program yang benar secara $100 \%$.

Pengujian White Box Testing dapat dilakukan sebagai berikut :

a. $\mathrm{V}(\mathrm{G})=\mathrm{E}-\mathrm{N}+2$ hasilnya sama dengan $\mathrm{V}(\mathrm{G})=\mathrm{P}+1$

b. Flowgraph mempunyai region yang sama dengan jumlah $\mathrm{V}(\mathrm{G})$ maka sistem dikatakan sudah terbukti efektif dan efisien.

\section{Flow Graph Nation}

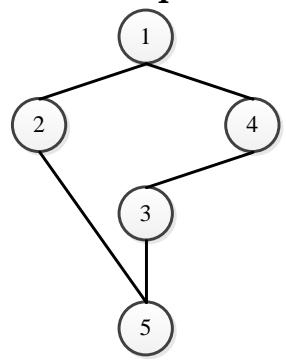


Gambar 15. Flow Graph Nation

Keterangan Gambar :

Region $(\mathrm{R})=1$

Node $(\mathrm{N})=5$

Edge $\quad(\mathrm{E})=5$

Predicate Node $(\mathrm{P})=1$

Node 1: Proses pemanggilan data user dan password dari database

Node 2 : Cek input username dan password

Node 3 : username dan password benar

Node 4 : cek kesesuaian username dan password

Node 5 : hasil proses login.

\section{KESIMPULAN}

Berdasarkan hasil penelitian dan pembahasan yang telah dilakukan, maka dapat ditarik kesimpulan sebagai berikut:

Aplikasi presensi perkuliahan dengan fingerprint berbasis web dan sms gateway, menjadi aplikasi yang memiliki keakuratan dalam proses input presensi yang dilakukan oleh mahasiswa dan dosen. Serta system presensi yang telah dibangun mampu memberikan kemudahan bagi civitas akademik yang terlibat dalam mengelola pelaporan dan perhitungan presensi secara efektif dan efisien.

\section{Saran}

Untuk kedepannya diharapkan dalam proses pengembangan aplikasi presensi sudah terintegrasi dengan system yang lain, seperti system parkir, dan pelayanan akademik yang lainyya yang menggunakan proses verifikasi berbasis fingerprint. Serta untuk system pelaporan presensi dapat dikembangkan dengan platform yang lain seperti smartphone android yang mudah diakses dan memberikan kemudahan bagi penggunanya.

\section{DAFTAR PUSTAKA}

Agus Saputra (2011). Trik dan Solusi Jitu Pemrograman PHP. IKAPI., Jakarta;

Andriyat Krisdiawan, Rio, M. Wahyuddin, and M. Zaini Rois. "SISTEM PENGELOLAAN LABORATORIUM KOMPUTER

(StudiKasusFakultasIlmuKomputerUnivers itasKuningan)." SISTEM PENGELOLAAN LABORATORIUM KOMPUTER
(StudiKasusFakultasIlmuKomputerUnivers itasKuningan) (2011).

Chaffey, D., 2009, E-Business and ECommerce Management: Strategy, Implementation and Practice, 4th edition, Prentice Hall;

Coad, Peter and Yourdon, Edward. ObjectOriented Analysis, Yourdon Press, 1991.

Coad, Peter and Yourdon, Edward. ObjectOriented Design Second Edition, Yourdon Press. 1991.

Eko Budi Setiawan, Perancangan Sistem Absensi Kehadiran Perkuliahan dengan Menggunakan Radio Frequency Identification (RFId), Jurnal CoreIT, Vol.1, No.2, Desember 2015;

Fatansyah, Ir. (2007).”Basis Data”. Bandung: Informatika Bandung.

Fowler, Martin.UML Distiled: Panduan Singkat Bahasa Pemodelan Object Standar, Edisi 3, Penerbit Andi: Yogyakarta. 2004.

Hendrayudi. 2008, Visual Basic Untuk Berbagai Keperluan Pemrograman, Yogyakarta: Elex Media Komputindo;

Khoirur Rozikin, Kasih Purwantini, "Pengaruh Sistem Presensi dengan Deteksi Sidik jari dan SMS Gateway Terhadap Tingkat membolos Siswa" Seminar Nasional Teknologi Informasi \& Komunikasi Terapan 2014,Semantik 2014;

Kruchten, Philippe, The Rational Unified Process An Introduction, Second Edition, John Wiley and Son Ltd. 2006.

Mardiyantoro Nahar, Model Presensi Berbasis Fingerprint Dan Short Message Service Sebagai Media Pemantau Kehadiran Dan Poin Pelanggaran Siswa, Jurnal Teknologi Informasi, Volume 10 Nomor 1, April 2014, ISSN 1414-9999;

Mcleod Jr, Raymond, George P Schell. (2007). Management Information Systems. ( $10^{\text {th }}$ Edition). USA: Pearson Prentice Hall; Muslim, 2006. Fingerprint Pattern Recognition Using Distance Method Algorithm. Syah Kuala University, Darussalam-Banda Aceh;

Noval Aditya Muhammad, Pembuatan Aplikasi Presensi Perkuliahan Berbasis Fingerprint (Studi Kasus : Jurusan Sistem Informasi Institut Teknologi Sepuluh Nopember Surabaya), JURNAL TEKNIK 
POMITS Vol. 2, No. 3, (2013) ISSN: 2337-3539;

Nugroho Adi.Rekayasa Perangkat Lunak Berorientasi Objek dengan metode USDP (Unified Software Development Process),Penerbit Andi:Yogyakarta. 2010.

Nugroho.Adi. 2009. Rekayasa Perangkat Lunak Menggunakan UML \& Java. Yogyakarta: Andi Offset;

Pressman, Roger S. (2007). Rekayasa Perangkat Lunak: pendekatan praktisi (Buku1). Beizer, B. (1995). Black-Box Testing, Wiley. Yogyakarta: Andi.

Remick, Jarel. (2011). What Is a Web App? Here's Our Definition, http://web.appstorm.net, dilihat 17 Mei 2017; 